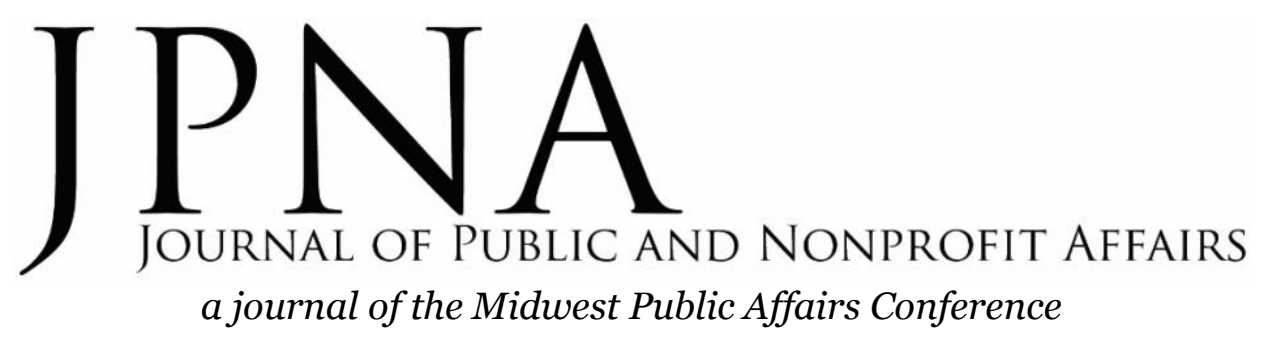

\title{
Spring 2021
}

\section{Volume 7, Number 1}

Inaugural Editor's Introduction: What Have We Learned From 'The Lost Year'?

Deborah A. Carroll ........................................

\section{Research Articles}

District Reliance by Service Function: A Study of Public Financing of American Special Districts

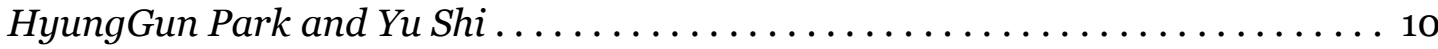

Local Government Fiscal Early Warning Surveys: Lessons From COVID-19

Geoffrey Propheter and Melissa Mata ............................. 29

The Managerial Apprenticeship of FDR's Budget Director: Harold D. Smith and the Michigan Municipal League, 1928-1937

Mordecai Lee ........................................ 46

Ethics in the Hollow State: Distinguishing Between Nonprofit and For-Profit Agents of Prisoner Reentry

LeAnn Beaty . . .

The Paradox of Employee-Volunteer Interchangeability in a Supported Social Enterprise Kunle Akingbola and Suwimon Phaetthayanan ................... 89

Understanding Conflict in Multisite Nonprofit Organizations

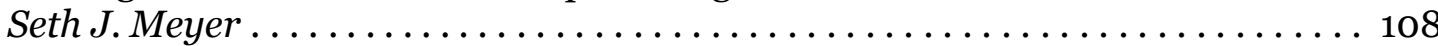

\section{Current Issues in Practice}

Native American Homelessness and Minneapolis' Infamous Tent City: Dispelling Myths and Stereotypes to Uncover Solutions Jeanine R. Jackson and Crystal S. Fashant . . . . . . . . . . . . . . . . 129

\section{Social Equity}

Social Inequities Highlighted by the Prolonged Pandemic: Expanding Sick Leave Beth M. Rauhaus and Andrew F. Johnson . . . . . . . . . . . . . . . . . . . . . 154

\section{Book Review}

Nonprofit Hero: Five Easy Steps to Successful Board Fundraising by Valerie M. Jones Crystal Trull .......................................... 164 
